University of Nebraska - Lincoln

DigitalCommons@University of Nebraska - Lincoln

Faculty Publications: Department of

Entomology

Entomology, Department of

2008

\title{
Predation of the Chinch Bug, Blissus occiduus Barber (Hemiptera: Blissidae) by Geocoris uliginosus (Say) (Hemiptera: Lygaeidae)
}

\author{
J. D. Carstens \\ University of Nebraska-Lincoln \\ Frederick P. Baxendale \\ University of Nebraska-Lincoln, fbaxendale1@unl.edu \\ Tiffany Heng-Moss \\ University of Nebraska-Lincoln, thengmoss2@unl.edu \\ Robert J. Wright \\ University of Nebraska, rwright2@unl.edu
}

Follow this and additional works at: https://digitalcommons.unl.edu/entomologyfacpub

Part of the Entomology Commons

Carstens, J. D.; Baxendale, Frederick P.; Heng-Moss, Tiffany; and Wright, Robert J., "Predation of the Chinch Bug, Blissus occiduus Barber (Hemiptera: Blissidae) by Geocoris uliginosus (Say) (Hemiptera: Lygaeidae)" (2008). Faculty Publications: Department of Entomology. 157.

https://digitalcommons.unl.edu/entomologyfacpub/157

This Article is brought to you for free and open access by the Entomology, Department of at DigitalCommons@University of Nebraska - Lincoln. It has been accepted for inclusion in Faculty Publications: Department of Entomology by an authorized administrator of DigitalCommons@University of Nebraska - Lincoln. 


\title{
Predation of the Chinch Bug, Blissus occiduus Barber (Hemiptera: Blissidae) by Geocoris uliginosus (Say) (Hemiptera: Lygaeidae)
}

\author{
J. D. Carstens, F. P. Baxendale, T. M. Heng-Moss, and R. J. Wright \\ Department of Entomology, University of Nebraska-Lincoln, Lincoln, NE 68583

\begin{abstract}
Big-eyed bugs have been well documented as predators on a diverse group of arthropod prey in turfgrasses; however, little is known about the big-eyed bug species associated with buffalograss, or their feeding habits relative to the western chinch bug, Blissus occiduus Barber. This research documented that Geocoris uliginosus (Say) was the predominant big-eyed bug species associated with buffalograss, obtained information on its feeding behavior, and characterized predation rates. Laboratory studies documented G. uliginosus, as a predator of B. occiduus. While all life stages of B. occiduus were attacked by G. uliginosus, predation was greater on $1^{\text {st }}$ through $4^{\text {th }}$ instars than on $5^{\text {th }}$ instars or adults. Low $5^{\text {th }}$ instar and adult chinch bug mortality was likely the result of their larger biomass, as well as their superior size and strength compared to younger $\left(1^{\text {st }}\right.$ through $4^{\text {th }}$ instar $)$ chinch bugs. The mean number of $1^{\text {st }}$ through $3^{\text {rd }}$ instar chinch bugs consumed by G. uliginosus at each evaluation period was higher than for $5^{\text {th }}$ instar or adult chinch bugs. Based on this research, chinch bug management decisions should take into consideration big-eyed bug densities, especially when the majority of $B$. occiduus are early $\left(1^{\text {st }}-2^{\text {nd }}\right)$ instars.

KEY WORDS: Big-eyed bugs, beneficial arthropods, buffalograss, biological control, chinch bugs
\end{abstract}

Buffalograss, Buchloë dactyloides (Nuttall) Engelmann, is a warm-season grass native to the short-grass prairies of the Central Great Plains. It is well known for its drought tolerance, superior erosion control, sod forming ability, and relative freedom from insect pests and diseases (Beard, 1973). Once established, buffalograss requires substantially less water than most widely planted cool-season turfgrasses (Riordan et al., 1998). In recent years, there has been increased use of this short, fineleaved prairie grass as an attractive, alternative turf that can be grown under both low and high maintenance regimes (Riordan et al., 1998).

The expanding use of buffalograss calls for a better understanding of the arthropods associated with this increasingly popular turfgrass. Among the arthropods known to inhabit buffalograss stands is the western chinch bug, Blissus occiduus Barber, which has emerged as a serious pest across the Central Great Plains of the United States (Baxendale et al., 1999; Vittum et al., 1999). Currently, the reported distribution of B. occiduus includes California, Arizona, Oklahoma, Colorado, Kansas, Montana, Nebraska, and New Mexico in the United States, and Alberta, British Columbia, Manitoba, and Saskatchewan in Canada (Bird and Mitchener, 1950; Slater, 1964; Baxendale et al., 1999).

Among the beneficial arthropods known to be associated with buffalograss are big-eyed bugs, spiders, ants, ground beetles, rove beetles, and several species of parasitoid wasps (Heng-Moss et al., 1998; Carstens et al., 2007). Of these natural enemies, the big-eyed bug, Geocoris spp., has been identified as an important predator of numerous insect pests in both agricultural and turfgrass systems (Dunbar, 1971; Mailloux, 1976; Reinert, 1978; Crocker and Whitcomb, 1980; Medal

Accepted 26 June 2008; Revised 8 September 2008

(C) 2008 Kansas Entomological Society 
et al., 1995; Heng-Moss et al., 1998; Baxendale et al., 1999; Carstens et al., 2007). Heng-Moss et al. (1998) and Carstens et al. (2007) reported finding big-eyed bugs (species not reported) in buffalograss turf, and speculated they could be feeding on the western chinch bug. At least 25 species of Geocoris occur in America north of Mexico in numerous habitats (Ashlock and Slater, 1988).

Big-eyed bugs have been well documented as predators on a diverse group of arthropod prey in turfgrasses, including Blissus spp. (Dunbar, 1971; Mailloux, 1976; Reinert, 1978; Baxendale et al., 1994). Reinert (1978) reported G. uliginosus to be the most numerous and frequently encountered predator in Florida turf. Reinert (1978) observed G. uliginosus feeding on all stages of the southern chinch bug, B. insularis, and recorded an average of $9.6 \pm 3.3$ chinch bug nymphs consumed by a single bigeyed bug over a five day period under laboratory conditions. Dunbar (1971) recorded G. uliginosus as a predator of the hairy chinch bug, B. l. hirtus in Connecticut turfgrass, while Mailloux (1976) identified G. bullatus as a natural enemy occurring in New Jersey turfgrass.

Several researchers have investigated the feeding preferences of big-eyed bugs. Crocker and Whitcomb (1980) reported that under field conditions, 97\% of 140 target insect prey of Geocoris spp. were adults, larvae, or nymphs. Predation on eggs and pupae accounted for only 3\%. Crocker and Whitcomb (1980) also studied the host range of $G$. bullatus, G. punctipes, and G. uliginosus and reported 67 host species including 3 classes of arthropods, plants, seeds, dead insects, and even insect feces. These reports document the diversity of food items consumed by Geocoris spp. under field conditions.

Although big-eyed bugs have been well documented as predators of arthropod prey in turfgrasses, little is known about the big-eyed bug species associated with buffalograss, or their feeding habits relative to B. occiduus. Accordingly, the objectives of this research were to document the big-eyed bug species associated with buffalograss, obtain information on big-eyed bug feeding behavior, and characterize their predation of $B$. occiduus.

\section{Materials and Methods}

Big-eyed bugs were collected from buffalograss research plots at the John Seaton Anderson (JSA) Facility, near Mead, NE. Preserved specimens were sent to Dr. Thomas J. Henry at the Systematics Entomology Laboratory in Beltsville, MD where they were subsequently identified as Geocoris uliginosus (Say) and G. limbatus Stal (Lygaeidae) (Readio and Sweet, 1982). Geocoris uliginosus was investigated in this study because they represented ca. $60 \%$ of the big-eyed bugs present and were consistently abundant in buffalograss turf throughout the growing season.

\section{Feeding Behavior}

Big-eyed bug feeding behavior was documented for each chinch bug life stage $\left(1^{\text {st }}\right.$ $2^{\text {nd }}, 3^{\text {rd }}, 4^{\text {th }}, 5^{\text {th }}$ instars, and adults) during both generations by visually observing 10 big-eyed bugs for 30 min during an attack on a single chinch bug.

\section{Chinch Bug Mortality Studies}

The mortality of $1^{\text {st }}$ through $5^{\text {th }}$ instar and adult $B$. occiduus (sex undetermined) in the presence and absence of a single $5^{\text {th }}$ instar G. uliginosus (sex undetermined) was evaluated in a series of non-choice studies. Chinch bugs were collected from ' 378 ' 
buffalograss at the JSA Facility located near Mead, NE by vacuuming the soil surface with a modified ECHO Shred 'N Vac (Model \#2400, ECHO Incorporated, Lake Zurich, IL) (Eickhoff, 2004). Collected chinch bugs were confined in clear plastic bags $(30.5 \times 15.3 \times 61.0 \mathrm{~cm})$ along with fresh buffalograss clippings until being sifted through a $2 \mathrm{~mm}$ mesh screen and collected with an aspirator. Chinch bugs were subsequently held for $24 \mathrm{hr}$ in plastic cups $(3.8 \mathrm{~cm}$ in diameter and $3.8 \mathrm{~cm}$ in height) with fitted lids so injured and dead individuals could be identified and discarded prior to initiation of experiments.

Fifth instar $G$. uliginosus nymphs were individually hand-collected at the same time and location as B. occiduus. Big-eyed bugs were held for $24 \mathrm{hr}$ without food in the previously described plastic cups. All big-eyed bugs were inspected for injury and replaced as necessary before initiating experiments. In order to standardize their age, only $5^{\text {th }}$ instar big-eyed bugs were used in this study.

The buffalograss cultivar '378' (acquired from Dr. Robert Shearman, University of Nebraska) was used to provide sustenance for chinch bugs during all experiments. This cultivar is known to be an excellent host for B. occiduus (Heng-Moss et al., 2002). Flats of ' 378 ' buffalograss were maintained in the greenhouse under 400 -watt high-intensity discharge lamps with a 16:8 (L:D) h photoperiod, and were fertilized weekly with a soluble 20.0-4.4-16.6 (20N-10P-20K) fertilizer. Two to three rooted 378 sprigs were placed in small, glass vials filled with water, fitted with cotton plugs, and the tops wrapped with 'Parafilm ${ }^{\circledR}$ M' laboratory film. Vials were individually glued to the bottom of plastic arenas $(16.51 \mathrm{~cm}$ in diameter and $6.35 \mathrm{~cm}$ in height) with a hot glue gun to prevent rolling during handling.

Both first and second B. occiduus generations (Baxendale et al., 1999) were investigated in this study. Treatments consisted of arenas with one fifth instar G. uliginosus, and either ten or 20 chinch bugs of the designated life stage. Controls were identical, but did not include a big-eyed bug. These controls served to document $B$. occiduus mortality under test conditions.

First generation: Twenty chinch bugs were used for each life stage tested, except during evaluation of adults, when experiments included only ten chinch bugs because preliminary studies (unpubl. data) suggested big-eyed bugs take longer to consume larger prey. First and $2^{\text {nd }}$ instar $B$. occiduus were grouped because they are tiny and nearly indistinguishable. To ensure all adult chinch bugs were similar in age, $5^{\text {th }}$ instar nymphs were collected and held until reaching the adult stage.

Second generation: Studies evaluating mortality of second generation chinch bugs by $G$. uliginosus followed the previously described procedures, but employed only ten, $5^{\text {th }}$ instar chinch bugs.

Studies were completely randomized with 12-18 replications per treatment, and were blocked by environmental chamber. Three environmental chambers maintained at $26 \pm 1{ }^{\circ} \mathrm{C}$ and 14:10 (L:D) h were used throughout the experiment. Chinch bug mortality was documented by recording the number of dead chinch bugs at $1 \mathrm{hr}$, $3 \mathrm{hr}, 6 \mathrm{hr}, 12 \mathrm{hr}$, and $24 \mathrm{hr}$ after G. uliginosus introduction, and every $24 \mathrm{hr}$ thereafter. Experiments were terminated when approximately $90 \%$ of chinch bugs in big-eyed bug-containing arenas in all replications were dead.

\section{Chinch Bug Dry Weights}

Chinch bug dry weights were measured to estimate age class specific biomass. One hundred chinch bugs of each non-egg life stage $\left(1^{\text {st }}, 2^{\text {nd }}, 3^{\text {rd }}, 4^{\text {th }}, 5^{\text {th }}\right.$ and adults $)$ were 
placed in a drying oven for $48 \mathrm{hr}$. Dried chinch bugs were weighed and their total biomass was divided by 100 to calculate the average biomass of a single chinch bug for each life stage.

\section{Estimated Chinch Bug Consumption}

Estimated consumption of each B. occiduus life stage by $G$. uliginosus was calculated by subtracting the mean number of dead chinch bugs recorded in arenas containing big-eyed bugs from the mean number of dead chinch bugs found in control arenas during each time interval. These consumption estimates assumed that a portion of the dead chinch bugs in arenas containing big-eyed bugs had died of "natural" causes, while the remaining dead chinch bugs were killed by G. uliginosus.

\section{Statistical Analyses}

Data were analyzed using the split-plot in time mixed model analysis (PROC MIXED, SAS Institute, 1999) to detect differences in B. occiduus mortality in containers containing big-eyed bugs and controls over time. In addition, differences between generations were also analyzed. When appropriate, means were separated using Fisher's LSD procedure. All effects with $P$-values less than or equal to 0.05 were considered significant.

\section{Results and Discussion}

\section{Feeding Behavior}

The behavior of G. uliginosus feeding on B. occiduus was similar to observations of Geocoris spp. feeding on other arthropods (Crocker and Whitcomb, 1980). Following the introduction of G. uliginosus into an arena, G. uliginosus would rapidly move around the arena seeking protection in the buffalograss sprigs provided. Occasionally, G. uliginosus were observed feeding on the buffalograss, which likely provided supplemental nutrients and/or moisture for growth and development.

Big-eyed bugs captured B. occiduus by inserting their beak (apparently randomly) into the head, thorax, or abdomen of the chinch bug. After insertion of their beak, the prey was typically suspended in the air. This seemed to reduce the effectiveness of chinch bug struggling by minimizing contact with the substrate. Upon completion of feeding, G. uliginosus used its front legs to remove the chinch bug and clean its mouthparts.

Occasionally, a $5^{\text {th }}$ instar or adult chinch bug under attack would take advantage of its large size and strength to escape the big-eyed bug. Interestingly, Crocker and Whitcomb (1980) found that the highest percentage of prey successfully captured and consumed by Geocoris spp. were those that remained passive during attack by the predator. These behaviors may help explain the lower consumption rates of later instars and adult chinch bugs.

\section{Chinch Bug Mortality Studies}

Mixed model analyses of chinch bug mortality detected a significant interaction among chinch bug generation, age class, and time for all chinch bug age classes except adults $\left(1^{\text {st }}-2^{\text {nd }}\right.$ instar: $F=5.7$; d.f. $=10,379 ; P<0.0001 ; 3^{\text {rd }}$ instar: $F=4.0$; d.f. $=16,589 ; P<0.0001 ; 4^{\text {th }}$ instar: $F=2.9$; d.f. $=20,725 ; P<0.0001 ; 5^{\text {th }}$ instar: $F$ 

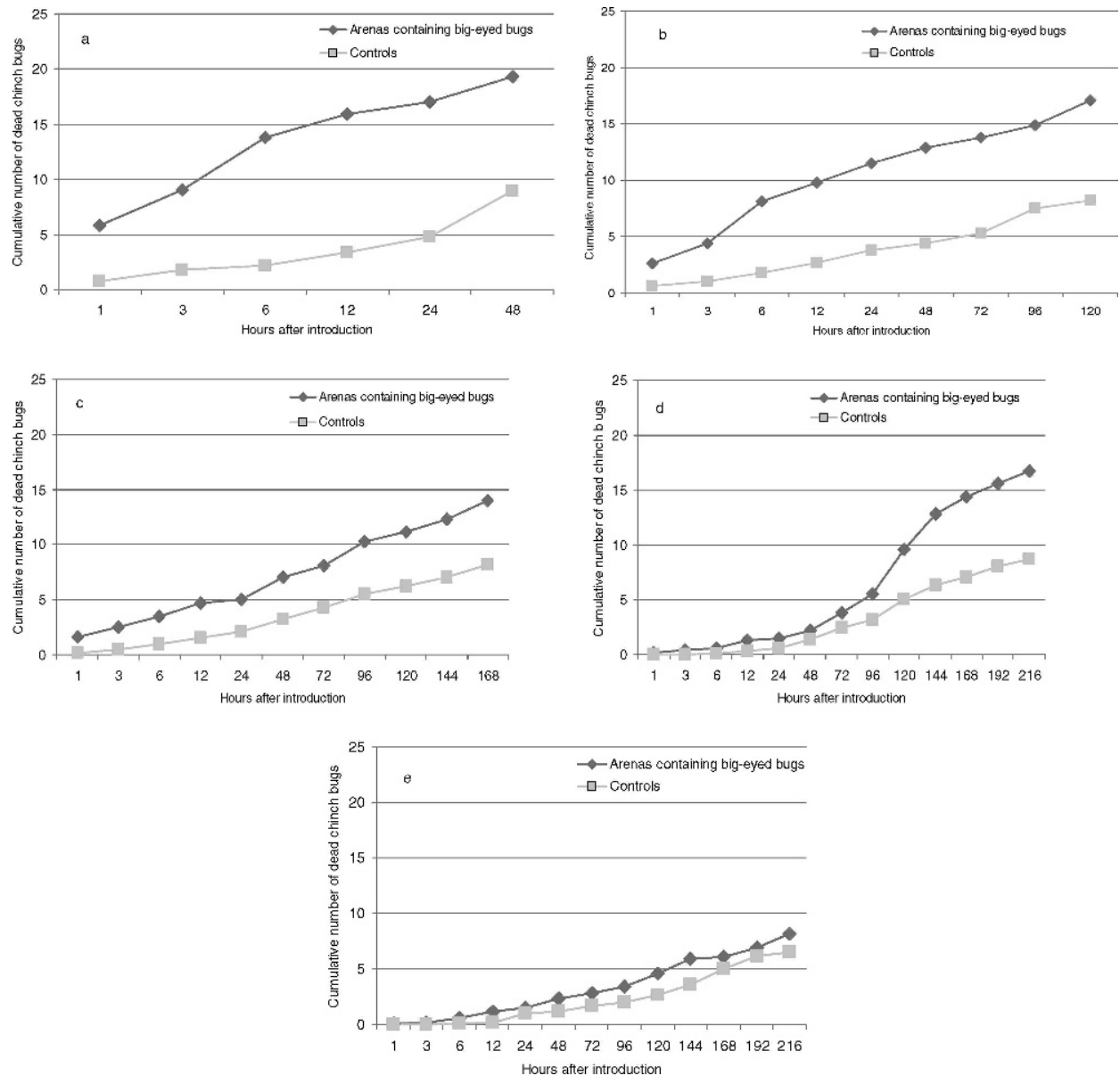

Fig. 1. Cumulative number of dead chinch bugs for selected life stages, first generation: (a) $1^{\text {st }}-2^{\text {nd }}$ instars, (b) $3^{\text {rd }}$ instars, (c) $4^{\text {th }}$ instars, (d) $5^{\text {th }}$ instars, and (e) adults.

$=5.9$; d.f. $=24,705 ; P<0.0001$; adults: $F=1.1$; d.f. $=24,555 ; P<0.40)$. Despite significant differences in the patterns of chinch bug mortality between the first and second generations, results were similar for both generations.

First generation: First and second instar chinch bugs: There was a significant interaction between chinch bug age class and time $(F=16.1$; d.f. $=5,185 ; P<$ $0.0001)$. The mean number of dead chinch bugs in big-eyed bug-containing arenas was high (5.8) at $1 \mathrm{hr}$ after introduction, but decreased over the next $23 \mathrm{hr}$. Chinch bug mortality in the control arenas was relatively constant during this period, except during the last evaluation period (Fig. 1a). Significant differences in the mean number of dead chinch bugs between arenas containing big-eyed bugs and controls were observed at $1 \mathrm{hr}, 3 \mathrm{hr}$, and 6, h after introduction, but not at $12 \mathrm{hr}, 24 \mathrm{hr}$, and $48 \mathrm{hr}$ after introduction (Fig. 1a). The higher numbers of dead chinch bugs observed during early evaluations ( $1 \mathrm{hr}$ through $6 \mathrm{hr}$ after big-eyed bug introduction) suggests that starved big-eyed bugs immediately satiated themselves following the $24 \mathrm{hr}$ nonfeeding period. After $48 \mathrm{hr}, 96.4 \%$ of the twenty $1^{\text {st }}-2^{\text {nd }}$ instar chinch bugs in bigeyed bug-containing arenas were dead compared to $45.3 \%$ in the controls. The high 
level of natural mortality in control arenas was likely due to the small and fragile nature of $1^{\text {st }}$ and $2^{\text {nd }}$ instar chinch bugs which made them highly vulnerable to desiccation and injury.

Third instar chinch bugs: There was a significant interaction between chinch bug age class and time $(F=5.5$; d.f. $=8,287 ; P<0.0001)$. The mean number of dead chinch bugs in big-eyed bug containing arenas increased dramatically at $6 \mathrm{hr}$ after introduction, while at the same evaluation time only a modest increase in the number of dead chinch bugs in control arenas was observed (Fig. 1b). In addition, chinch bug mortality in control arenas unexpectedly increased at $96 \mathrm{hr}$ after introduction followed by a decrease in chinch bug mortality at $120 \mathrm{hr}$ after introduction. In contrast, the number of dead chinch bugs in big-eyed bug-containing arenas slightly increased at $96 \mathrm{hr}$ after introduction followed by an increase in chinch bug mortality. These differences likely resulted in the significant chinch bug age class by time interaction. The mean number of dead chinch bugs was significantly greater in arenas containing big-eyed bugs than controls at $1 \mathrm{hr}, 3 \mathrm{hr}, 6 \mathrm{hr}$, and $120 \mathrm{hr}$ after introduction (Fig. 1b). Higher mortalities were again observed during early evaluations ( $1 \mathrm{hr}$ and $6 \mathrm{hr}$ after big-eyed bug introduction), again suggesting that starved big-eyed bugs immediately satiated themselves following the $24 \mathrm{hr}$ starvation period. After $48 \mathrm{hr}, 64.7 \%$ of the twenty $3^{\text {rd }}$ instar chinch bugs in big-eyed bug-containing arenas were dead compared to $20.8 \%$ in the controls. These results indicate that big-eyed bug feeding behavior on $3^{\text {rd }}$ instar chinch bugs is similar to $1^{\text {st }}$ and $2^{\text {nd }}$ instars; i.e., big-eyed bugs satiation followed by a period of limited feeding.

Fourth instar chinch bugs: The main effect of chinch bug age class was not significant $(F=16.8$; d.f. $=1,2 ; P>0.06)$ (Fig. 1c). More chinch bugs were dead in big-eyed bug-containing arenas than controls. After $48 \mathrm{hr}, 35.0 \%$ of the twenty $4^{\text {th }}$ instar chinch bugs in big-eyed bug-containing arenas were dead compared to $15.3 \%$ in the controls.

Fifth instar chinch bugs: There was a significant interaction between chinch bug age class and time $(F=2.6$; d.f. $=12,423 ; P<0.002)$. Differences between the mean number of dead chinch bugs in big-eyed bug containing arenas and control arenas were most pronounced at $96 \mathrm{hr}$ through $168 \mathrm{hr}$ after introduction compared to the other time periods evaluated (Fig. 1d). This difference likely led to the significant treatment by time interaction. Significantly more chinch bugs were dead in arenas containing big-eyed bugs than controls at $96 \mathrm{hr}, 120 \mathrm{hr}, 144 \mathrm{hr}$, and $168 \mathrm{hr}$ after introduction (Fig. 1d). After $48 \mathrm{hr}, 10.3 \%$ of the twenty $5^{\text {th }}$ instar chinch bugs in bigeyed bug-containing arenas were dead compared to $7.2 \%$ in the controls.

Adult chinch bugs: There was a significant interaction between chinch bug age class and time $(F=3.3$; d.f. $=12,273 ; P<0.0002)$. The general pattern of adult chinch bug mortality was similar during all evaluation periods, except chinch bug mortality in big-eyed bug-containing arenas decreased and then rebounded at 168 and $192 \mathrm{hr}$ after introduction, respectively, while B. occiduus mortality increased then decreased during the same evaluation periods (Fig. 1e). At $216 \mathrm{hr}$ after introduction, the number of dead adult chinch bugs between big-eyed bug-containing and control arenas was significantly different (Fig. 1e). After $48 \mathrm{hr}, 22.5 \%$ of the ten adult chinch bugs in big-eyed bug-containing arenas were dead compared to $11.7 \%$ in the controls.

Second generation: In general, chinch bug mortality patterns were similar for all life stage in arenas containing big-eyed bugs for both generations. However, chinch 

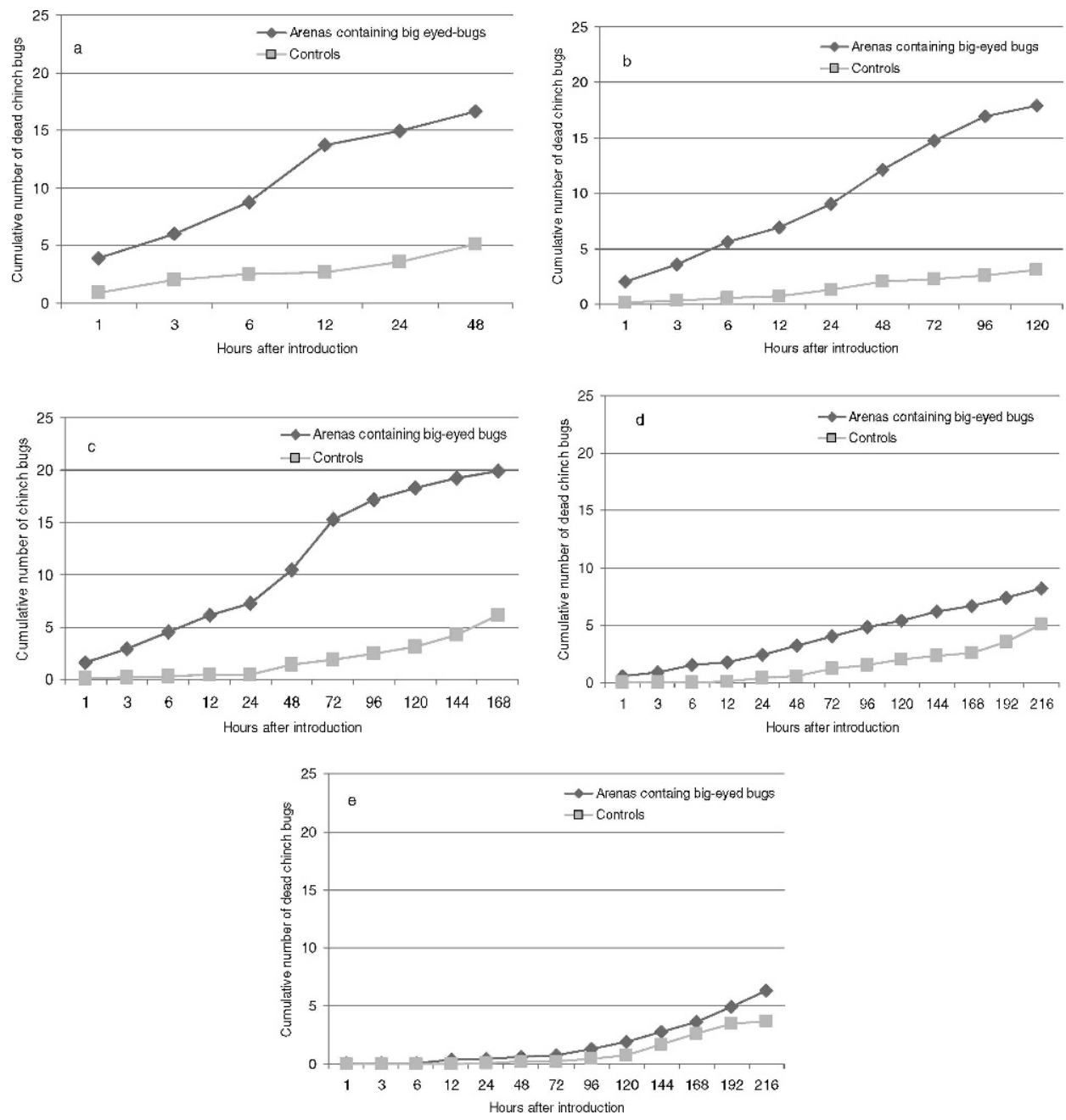

Fig. 2. Cumulative number of dead chinch bugs for selected life stages, second generation: (a) $1^{\text {st }}-2^{\text {nd }}$ instars, (b) $3^{\text {rd }}$ instars, (c) $4^{\text {th }}$ instars, (d) $5^{\text {th }}$ instars, and (e) adults.

bug mortality in control arenas was consistently lower for second generation experiments. This likely resulted from improvements in chinch bug collection and handling techniques.

First and second instar chinch bugs: There was a significant interaction between chinch bug age class and time $(F=10.8$; d.f. $=5,179 ; P<0.0001)$. The mean number of dead chinch bugs in arenas containing big-eyed bugs was significantly different from controls at 1, $6 \mathrm{hr}$, and $12 \mathrm{hr}$, but not at $3 \mathrm{hr}, 24 \mathrm{hr}$, and $48 \mathrm{hr}$ after introduction (Fig. 2a). The higher number of dead chinch bugs observed during earlier evaluation periods ( $1 \mathrm{hr}$ and $12 \mathrm{hr}$ after big-eyed bug introduction) is consistent with results from $1^{\text {st }}$ generation experiments where starved big-eyed bugs immediately satiated themselves following the $24 \mathrm{hr}$ non-feeding period. After $48 \mathrm{hr}$, $82.5 \%$ of the twenty $1^{\text {st }}-2^{\text {nd }}$ instar chinch bugs in big-eyed bug-containing arenas were dead compared to $24.7 \%$ in the controls. 
Third instar chinch bugs: The mean number of dead chinch bugs was consistently higher in big-eyed bug-containing arenas than control arenas at all evaluation periods (Fig. 2b). The main effect of chinch bug age class was significant $(F=117.0$; d.f. $=1,2 ; P<0.008)$. The mean number of dead chinch bugs was higher in arenas containing big-eyed bugs $(2.0 \pm 0.1)$ than in control arenas $(0.3 \pm 0.1)$ at all time periods evaluated except at $120 \mathrm{hr}$ after introduction. After $48 \mathrm{hr}, 60.0 \%$ of the twenty $3^{\text {rd }}$ instar chinch bugs in big-eyed bug-containing arenas were dead compared to $9.2 \%$ in the controls.

Fourth instar chinch bugs: There was a significant interaction between chinch bug age class and time $(F=6.4$; d.f. $=10,355 ; P<0.0001)$. The mean number of dead chinch bugs in arenas containing big-eyed bugs dramatically increased then decreased at 48 and $96 \mathrm{hr}$ after introduction, respectively, while only a slight increase in the number of dead chinch bugs in control arenas was observed during the same evaluation periods (Fig. 2c). Interestingly, chinch bug mortality increased during the last two evaluation periods in control arenas, while chinch bug mortality in big-eyed bug containing arenas decreased (Fig. 2c).

Significant differences in the mean number of dead chinch bugs in arenas containing big-eyed bugs were observed among the evaluation periods. There were significant differences in the number of dead chinch bugs between arenas containing big-eyed bugs and controls at $1 \mathrm{hr}$ through $96 \mathrm{hr}$ after introduction (Fig. 2c). After $48 \mathrm{hr}, 52.2 \%$ of the twenty $4^{\text {th }}$ instar chinch bugs in big-eyed bug-containing arenas were dead compared to $6.3 \%$ in the controls.

Fifth instar chinch bugs: Chinch bug mortality in big-eyed bug-containing arenas was relatively consistent over time (Fig. 2d). The main effect of chinch bug age class was significant $(F=25.5$; d.f. $=1,2 ; P<0.04)$. The mean number of dead chinch bugs was higher in arenas containing big-eyed bugs $(0.6 \pm 0.1)$ than in controls $(0.3$ $\pm 0.1)$. After $48 \mathrm{hr}, 30.8 \%$ of the ten $5^{\text {th }}$ instar chinch bugs in big-eyed bugcontaining arenas were dead whereas $6.9 \%$ were dead in the controls.

Adult chinch bugs: Similar to $5^{\text {th }}$ instar chinch bug results, mortality of adult chinch bugs in big-eyed bug-containing arenas paralleled the controls (Fig. 2e). The main effect of chinch bug age class was not significant $(F=4.3 ;$ d.f. $=1,2 ; P>$ 0.17 ). After $48 \mathrm{hr}, 5.8 \%$ of the ten adult chinch bugs in big-eyed bug-containing arenas were dead compared to $2.5 \%$ in the controls.

These studies demonstrate that G. uliginosus consumes all non-egg chinch bug stages. Following a period of non-feeding, big-eyed bugs typically satiate themselves as soon as possible then enter a period of limited feeding before feeding again. Our results (first and second generation) support the hypothesis that big-eyed bugs consume larger numbers of early instar chinch bugs than later instars or adults. These results support the observations of Richman et al. (1980) who reported that consumption of small soybean looper larvae, Pseudoplusia includens (Walker), was highest for both $G$. punctipes and G. uliginosus. Similarly, Medal et al. (1995) suggested the higher mortality of the smaller nymphal stages $\left(1^{\text {st }}\right.$ through $\left.3^{\text {rd }}\right)$ of Spissistilus festinus by $G$. punctipes was due to their high susceptibility to big-eyed bug attack.

\section{Chinch Bug Dry Weights}

Mean dry weights for a single chinch bug of each life stage were: $1^{\text {st }}$ instar $=$ $0.010 \mathrm{mg} ; 2^{\text {nd }}$ instar $=0.023 \mathrm{mg} ; 3^{\text {rd }}$ instar $=0.037 \mathrm{mg} ; 4^{\text {th }}$ instar $=0.055 \mathrm{mg} ; 5^{\text {th }}$ instar $=0.203 \mathrm{mg}$; adult $=0.327 \mathrm{mg}$. 


\section{Estimated Chinch Bug Consumption}

Because there were statistical differences in chinch bug consumption between first and second generation, estimated chinch bug consumption by $G$. uliginosus is reported separately for each generation.

First generation: The mean number of $1^{\text {st }}-2^{\text {nd }}$ and $3^{\text {rd }}$ instar chinch bugs consumed by $G$. uliginosus at each evaluation period was higher than for $5^{\text {th }}$ instar or adult chinch bugs. Chinch bug mortality at later (12 hr, $24 \mathrm{hr}$, and $48 \mathrm{hr}$ ) evaluations was relatively consistent over time. Interestingly, the mortality of $5^{\text {th }}$ instar chinch bugs was higher than that of $4^{\text {th }}$ instar chinch bugs at the $144 \mathrm{hr}$, $168 \mathrm{hr}, 192 \mathrm{hr}$, and $216 \mathrm{hr}$ evaluation periods.

Second generation: Second generation results were similar to those of first generation experiments for all chinch bug stages evaluated, except consumption of $3^{\text {rd }}$ and $4^{\text {th }}$ instar chinch bugs which were slightly higher than consumption of $1^{\text {st }}$ and $2^{\text {nd }}$ instar chinch bugs.

In general, mortality of $5^{\text {th }}$ instar and adult chinch bugs were lower than the other instars evaluated. Again, these differences may reflect the greater biomass of $5^{\text {th }}$ instars and adults. Since the mean biomass of one $5^{\text {th }}$ instar chinch bug is approximately equal to twenty $1^{\text {st }}$ instar chinch bugs, big-eyed bugs would be consuming approximately the same amount of chinch bug biomass over time.

\section{Conclusions}

This study confirmed the presence of the big-eyed bugs, G. uliginosus and $G$. limbatus in buffalograss turf, and investigated the feeding behavior and efficiency of G. uliginosus on B. occiduus. While all feeding life stages of B. occiduus were captured and consumed by $G$. uliginosus, predation was greater on $1^{\text {st }}$ through $4^{\text {th }}$ instars than on $5^{\text {th }}$ instars or adults. For example, after $48 \mathrm{hr}$ in first generation experiments, $96.4 \%$ of $1^{\text {st }}-2^{\text {nd }}$ instar chinch bugs were consumed in big-eyed bug containing arenas, whereas only $10.3 \%$ and $22.5 \%$ of $5^{\text {th }}$ instar and adult chinch bugs were consumed. It has been well documented that predators rarely attack all age or size classes of a prey species with equal frequency (Salt, 1967). In addition, the lower mortality of older chinch bugs likely reflects their larger size and superior strength. Laboratory observations documented that active $5^{\text {th }}$ instar and adult chinch bugs routinely evaded capture by the big-eyed bug predator. These observations support the findings of Crocker and Whitcomb (1980) who reported that the highest percentage of prey captured by Geocoris spp. were those that remained passive during an encounter with the predator.

These behaviors can have important implications for both predator and prey population dynamics. Research has shown that predation on earlier life stages has less impact on the prey's overall reproductive capacity than predation on older, reproductive individuals (Price, 1975). If G. uliginosus preferentially preys on $1^{\text {st }}$ through $4^{\text {th }}$ instar B. occiduus, its impact on the chinch bug population would be greatly reduced. Another factor that may have contributed to the lower mortality of $5^{\text {th }}$ instar and adult chinch bugs is their larger size. Since the average biomass of a single, $5^{\text {th }}$ instar chinch bug is equivalent to approximately twenty $1^{\text {st }}$ instar chinch bugs, the big-eyed bugs may be consuming the same relative chinch bug biomass over time.

The efficiency of big-eyed bugs as a chinch bug predator in the field is likely to be lower than observed in this laboratory study. These experiments were conducted in a 
relatively simple environment, where big-eyed bugs could easily locate and capture their confined prey. Under field conditions, chinch bugs would be much more difficult to locate, being protected by the dense turf and organic debris. Further, in these no-choice studies big-eyed bugs had no alternative but to consume the single life stage of the single prey species provided. Crocker and Whitcomb (1980) documented a host range for Geocoris spp. exceeding 67 plant and arthropod species, which represents a wide diversity of food items big-eyed bugs will consume under field conditions. In buffalograss turf, big-eyed bugs may feed on many other prey species (e.g., sod webworms, leafhoppers, spider mites, collembolans, grass-feeding mealybugs) as well as chinch bugs, thus reducing their potential as biological control agents for chinch bugs. Choice studies are needed to confirm big-eyed bug feeding preferences on all B. occiduus life stages, and their preferences for other arthropods commonly found in buffalograss. This information is essential for accurately assessing the potential of $G$. uliginosus as a biological control agent in buffalograss.

Geocoris uliginosus offers a potentially valuable alternative for managing chinch bugs in buffalograss. Currently, Geocoris spp. are being mass reared for augmentation biological control in various agricultural settings (Hunter, 1997). Inoculative releases of $G$. uliginosus could potentially suppress $B$. occiduus infestations in buffalograss. Currently, however, the most practical approach for reducing chinch bug populations using Geocoris spp. involves the judicious use of pesticides and careful application of cultural practices which conserve big-eyed bugs. This is especially important when early instar chinch bugs are present.

\section{Acknowledgements}

We gratefully acknowledge Tom Eickhoff and Steve Danielson for reviewing this manuscript. We also thank Jessica Hurd, Jim Kalisch, and Robert Roselle for technical assistance. This research was supported in part by the University of Nebraska Agriculture Experiment Station Project 17-062 and 17-078.

\section{Literature Cited}

Ashlock, P. D., and A. Slater. 1988. Family Lygaeidae. pp. 167-245. In T. J. Henry and R. C. Froeschner (eds.). Catalog of the Heteroptera, or True Bugs, of Canada and the Continental United States. E. J. Brill, Leiden. 958 pp.

Baxendale, F. P., J. M. Johnson-Cicalese, and T. P. Riordan. 1994. Tridicus sporoboli and Trionymus sp. (Homoptera: Pseudococcidae): potential new mealybug pests of buffalograss turf. Journal of the Kansas Entomological Society 67:169-172.

Baxendale, F. P., T. M. Heng-Moss, and T. P. Riordan. 1999. Blissus occiduus (Hemiptera: Lygaeidae): A chinch bug pest new to buffalograss turf. Journal of Economic Entomology 92(5):169-172.

Beard, J. B. 1973. Turfgrass: Science and Culture. Prentice-Hall, Inc., Englewood Cliffs, NJ. 658 pp.

Bird, R. D., and A. V. Mitchener. 1950. Insects of the season 1949 in Manitoba. Canadian Insect Pest Review 28:41.

Carstens, J., T. Heng-Moss, F. Baxendale, R. Gaussoin, K. Frank, and L. Young. 2007. Influence of buffalograss management practices on western chinch bug and its beneficial arthropods. Journal of Economic Entomology 100:136-147.

Crocker, R. L., and W. H. Whitcomb. 1980. Feeding niches of the big-eyed bugs Geocoris bullatus, G. punctipes, and G. uliginosus (Hemiptera: Lygaeidae: Geocorinae). Journal of Environmental Entomology 9:508-513.

Dunbar, D. M. 1971. Big-eyed bugs in Connecticut lawns. Connecticut Agriculture Experiment Station 244:6.

Eickhoff, T. E., F. P. Baxendale, T. M. Heng-Moss, and E. E. Blankenship. 2004. Turfgrass, crop and weed hosts of Blissus occiduus (Hemiptera: Lygaeidae). Journal of Economic Entomology 97:67-73. 
Frank, W. A., and J. E. Slosser. 1996. An illustrated guide to the predaceous insects of the northern Texas rolling plains. Texas Agricultural Experiment Station, MP-1718.

Heng-Moss, T. M., F. P. Baxendale, and T. P. Riordan. 1998. Beneficial arthropods associated with buffalograss. Journal of Economic Entomology 91(5):1167-1172.

Heng-Moss, T. M., F. P. Baxendale, T. P. Riordan, and J. E. Foster. 2002. Evaluation of buffalograss germplasm for resistance to Blissus occiduus. Journal of Economic Entomology 95(5):1054-1058.

Hunter, C. D. 1997. Suppliers of beneficial organisms in North America. California Environmental Protection Agency, Department of Pesticide Regulation, Environmental Monitoring and Pest Management Branch. 32 pp.

Mailloux, G. 1976. Life History of Blissus leucopterous hirtus Montandon (Hemiptera: Lygaeidae) in New Jersey, With Special Reference to Sampling of its Population. Ph.D. Dissertation. Rutgers University, New Brunswick, N.J. 210 pp.

Medal, J. C., A. J. Mueller, T. J. Kring, and E. E. Gbur, Jr. 1995. Developmental stages of Spissistilus festinus (Homoptera: Membracidae) most susceptible to hemipteran predators. The Florida Entomologist 78:561-564.

Price, P. W. 1975. Insect Ecology. John Wiley and Sons, Inc., Canada.

Readio, J., and M. H. Sweet. 1982. A review of the Geocorinae of the United States east of the $100^{\text {th }}$ Meridian (Hemiptera: Lygaeidae). Miscellaneous Publication of the Entomological Society of America 12:1-91.

Reinert, J. A. 1978. Natural enemy complex of the southern chinch bug in Florida. Annals of the Entomological Society of America 71:728-731.

Richman, D. B., R. C. Hemenway, Jr, and W. H. Whitcomb. 1980. Field cage evaluation of predators of the soybean looper, Pseudoplusia includens (Lepidoptera: Noctuidae). Journal of Environmental Entomology 9:315-317.

Riordan, T. P., F. P. Baxendale, R. E. Gaussoin, and J. E. Watkins. 1998. Buffalograss: an alternative native grass for turf. Nebraska Cooperative Extension, G96-1297-A.

Salt, G. W. 1967. Predation in an experimental protozoan population (Woodruffia Paramecium). Ecology Monograph 37:113-144.

SAS Institute. 1999. SAS/STAT Software: changes and enhancements through release 8.2. SAS Institute, Cary, NC. 352 pp.

Slater, J. A. 1964. A Catalogue of the Lygaeidae of the World. University of Connecticut, Storrs. $410 \mathrm{pp}$.

Vittum, P. J., M. G. Villani, and H. Tashiro. 1999. Turfgrass Insects of the United States and Canada, 2nd ed. Cornell University Press, Ithaca, NY. 422 pp. 